\title{
TML France: the civil engineering work for the Channel Tunnel in France
}

\author{
The construction director for the French section of the $£ 10$ billion \\ Channel Tunnel project was Pierre Matheron, a former project \\ director with SGE. He introduces this Special Issue by describing how the \\ French construction work was organized, how the decentralized \\ management met its objectives and how effective communication with up \\ to 4000 site staff was maintaned throughout the six-year construction \\ programme.
}

Let us briefly consider the works constructed on the French side of the Channel Tunnel. These consisted of

(a) more than $64 \mathrm{~km}$ of tunnels bored using five sophisticated, purpose-made tunnelling machines operating simultaneously

(b) a concrete segment prefabrication factory for the tunnel lining, specially built on site to produce 250000 tunnel segments at the rate of 9000 per month

(c) a terminal the size of an international airport (700 ha), the function of which is to load into the shuttles road vehicles equivalent to the circulation on a motorway (3450 vehicles an hour).

In addition to the technical challenges each of these elements represented, the most important feature of the project was the very tight programme which led to significant overlapping of the design, procurement, civil engineering and electrical and mechanical installation activities.

\section{Construction organization}

The French construction director was responsible to the project executive for all construction activities in France. In particular he was responsible for the budget, complying with the work programmes, and the management of all personnel in France. He supervised the activities of all the sub-projects and the French construction functional department directors over whom he had total authority.

\section{Sub-project operations}

During the tunnel-boring phase, operations were organized into four sub-projects

(a) tunnels

(b) prefabrication

(c) terminal

(d) electrical and mechanical installations.

After this first phase, which saw the end of the prefabrication of the tunnel lining segments, and for which the factory only remained open for the manufacture of the tunnel track sleeper blocks and the increase in the installation activities of the electrical and mechanical systems, the project was reorganized into two subprojects - tunnels and the terminal - which included civil as well as electrical and mechanical works. Each of these sub-projects was placed under the joint responsibility of a subproject director for the construction works and an engineering director for the design.

The sub-project construction director and the engineering director were jointly responsible for the technical, programme and performance aspects of their sub-project.

Each sub-project construction director

(a) defined the organization of the sub-project, and set up and managed his staff and labour force

(b) managed relations with the client

(c) managed productivity for the sub-project and was responsible for the technical choices for construction as well as programme productivity and establishing and complying with objectives

(d) decided the choice of sub-contractors and suppliers, awarded contracts and managed the various sub-contractors

(e) provided the administration and financial control for the sub-project.

Each engineering director was responsible for the design and optimization of his sub-project.

The sub-projects were subdivided into sections. Normally each work section was headed by a section manager who was responsible for cost control, programme and the choice of technical solutions for construction and, consequently, complying with objectives. It is worth noting that the level of responsibility of a construction section manager varied from Ffr. 50 million to Ffr.500 million; these amounts would normally be considered in the public sector as constituting a large project.

The functional departments provided, on behalf of the construction sections and under the responsibility of a department director, common services to the sub-projects, such as administrative, financial, commercial and technical services.
Proc. Instn Civ. Engrs Civ. Engng, Channel Tunnel, Part 3:

French Section 1994, 3-5

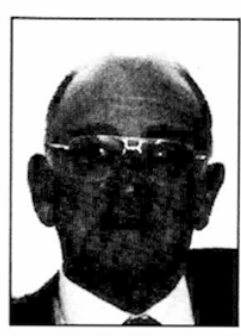

Pierre Matheron, Director, French Construction, GIE Transmanche Construction 
Functional departments

There were five functional departments

(a) administration/finance

(b) commercial

(c) project services

(d) human resources and communications

(e) quality assurance.

Generally, the responsibilities of the functional departments were

(a) to define the procedures for French construction, prepared in accordance with TML's general procedures, and to check compliance with the procedures by the subprojects

(b) to assist, on request, the sub-projects

(c) to centralize management information from the sub-projects for French construction for internal (management) and external use (sent to the client)

(d) to manage non-decentralized operations for the sub-project.

The functional directors had direct links with their corresponding section or service managers from the sub-projects. Instructions were issued in the form of procedures or by the director to the sub-project concerned. The organization of each functional department was modified for the second phase, as the electrical and mechanical works became more important than the civil engineering work. These departments were integrated during this phase, with the tunnel's sub-project and with the corresponding functional sections for the terminal sub-project.

\section{Management system and objectives}

In order to meet the complexity and extent of the works to be carried out - and this in a very short period of time--a decentralized management system was created. This system implied the following objectives for all French construction

(a) loyalty of people to the project and development of their capacity to work together

(b) a rigorous safety policy

(c) quality standards

(d) compliance with the programme

(e) control of costs.

In order to achieve these objectives, a management system based on clearly defined rules was set up in the following areas.

\section{Human resources}

The fundamental objectives for the personnel were professionalism, safety, employment, quality, information and communication.

In terms of employment, GIE Transmanche was committed to recruiting $75 \%$ of its labour locally from the north Pas-de-Calais region. Through a voluntary policy and collaboration with the Government and regional authorities, this figure has in fact reached $95 \%$. The local recruitment involved setting up special training schemes with all involved parties.

As for the staff, of which approximately half came from the French parent companies making up GIE Transmanche, a management participation structure was set up based on the open flow of information and establishing objectives at section levels.

\section{Safety}

A specialized service, in continuous contact with the technical and operational services, prepared the safety procedures. A strict accident prevention policy was created. The policy included an initial training course for all personnel on arrival, with complementary specialized training courses later (first-aid, national certificate of life-saving and resuscitation, electrical awareness, machines, lifting appliances), continuous $24 \mathrm{~h}$ presence of a professional fireman and nurse and two full-time doctors employed on the site.

\section{Quality}

A management system for quality, placed under the responsibility of specialists who had acquired extensive experience in this field on large construction projects, was set up. This provided a consensus of opinion on the advantages of strict quality management, not only for programming and costs, but also for good client relations. The quality system also trained and raised the awareness of all personnel. In the final event each person was responsible for the quality of production.

\section{Programme}

The project programme was divided in a similar manner to that of the organization and included the following levels

(a) Level 1: general programme, managed by the coordination structure

(b) Level 2: sub-project programme

(c) Level 3: section programme.

The periods allowed for each programme were managed by setting objectives at section levels which were consolidated at sub-project level. Level 3 programmes were prepared with the aid of computers and identified activities, interface and required resources. This level provided charts for progress, personnel needs and accounts.

Level 2 programmes included both the design and installation programmes for each sub. project. Lastly, the level 1 general programme was made up of the activities from the two subprojects.

\section{Costs}

Each sub-project was an independent profit centre. It controlled and managed its own costs 
and receipts

(a) by establishing and monitoring financial objectives

(b) by preparing a cost end-forecast twice a year

(c) by reviewing the cost end-forecast every three months.

The consolidation of the cost control activities and the preparation of reports were carried out by the project services department with assistance from the administrative and financial departments.

\section{Communication within the French construction operations}

The communication policy set-up had to meet the peculiar character of this large project, including the
(a) varied sources of personnel
(b) work regime (three shifts, seven days a week)
(c) size of the site
(d) location of the personnel (Paris, Calais, Sangatte, Coquelles and Great Britain)

(e) necessity of agreeing common policies, and a good knowledge of the project and its progress.

This policy centred along two main lines.

\section{Meetings}

The group directorate committee and the subprojects committees met once a week. This provided better information and helped decision making. Periodic information meetings were held for the whole work force and staff.

\section{Publications and audiovisual media}

Two publications, one fortnightly (L'ouvrage) and the other monthly, and the Franco-British The Link provided news on the progress of the project to all personnel. Every morning, messages on television screens gave details of daily activities on site to all offices.

An internal video network throughout the site provided an instant means of displaying messages, films or clips on work progress, safety, training, and hygiene. Moreover, a news video, transmitted monthly at first but then weekly, provided pictures from the daily life of the site to everyone. 